Review

\title{
About Gateway
}

\author{
Relly Victoria Virgil Petrescu and Florian Ion Tiberiu Petrescu
}

ARoTMM-IFToMM, Bucharest Polytechnic University, Bucharest, (CE) Romania

Article history

Received: $15-05-2020$

Revised: $19-05-2020$

Accepted: 23-05-2020

Corresponding Author:

Relly Victoria Virgil Petrescu

ARoTMM-IFToMM, Bucharest

Polytechnic University,

Bucharest, (CE) Romania

Email: rvvpetrescu@gmail.com

\begin{abstract}
After several postponements or even giving up, NASA finally decided to prepare and launch the long-delayed Moon space station Gateway, which had to be postponed for financial, technical reasons, but also for reasons and calculations about the possibility of assembling it in space and the way of transporting the main components in space, the main problem being the rockets capable of carrying such huge components in space. Today it seems that NASA has managed to solve all these problems and to finalize and in a real way all the details regarding such a complex undertaking.
\end{abstract}

Keywords: Nasa, Gateway, Space, Moon Space Station

\section{Introduction}

Man has always wanted to fly. Late he managed to do it and even in safer conditions and he thought that he should start exploring the cosmic space and in the future even conquer it. But how to conquer so immediately at least our universe that has about 2,000 billion galaxies, each with about 2,000 billion solar systems? With what to start with you ask yourself and the obvious answer is first with your galaxy and first of all with your own solar system where you are. Obviously, the easiest seemed to start with our satellite Luna, which we suspect (still) that is a natural one.

Although it seemed very easy to conquer the moon, even today man has not yet managed to do so. However, several decades after the first landing with a human crew on the Moon, NASA finally plans to return there with space stations, ships, research robots, related vehicles and the necessary crews today made up of specialized humans and robots. Various exploration tools, increasingly sophisticated devices, specialized weapons, vital protection systems will be needed. We already have the combined experience of terrestrial space stations that have been orbiting the Earth for many years, but also robots and spacecraft sent to the Moon, Mars, or for space exploration. It can be said now that we have some experience and equipment, money and technology, so the moment long-awaited by all mankind to have space stations around the Moon but then also on the Moon, seems to be fast approaching.

The moon is an astronomical body orbiting planet Earth, being its only permanent natural satellite. It is the fifth-largest natural satellite in the Solar System and the largest of the planetary satellites relative to the size of the planet it orbits (its primary object). According to
Jupiter's satellite, Io, the Moon is the second densest satellite of those whose densities are known.

The Moon is thought to have formed about 4.51 billion years ago, not long after Earth. There are several hypotheses for its origin; the most accepted explanation is that the Moon was formed from the remains left after a huge impact between the Earth and a body the size of Mars, called Theia.

The moon is in synchronous rotation with the Earth, ie it always shows the same face towards it, the visible part being marked by dark volcanic lunar seas, which fill the spaces between the high areas of the crust and the more prominent impact craters. Seen from Earth, it is the second celestial object visible from Earth in brightness after the Sun. Its surface is actually dark, although compared to the night sky it looks very bright, its reflectance being only slightly higher than that of used asphalt. Its gravitational influence produces ocean tides, land tides and a slight extension of the day.

The current orbital distance of the Moon is 384,400 $\mathrm{km}$ or 1.28 light-seconds. This value is about thirty times the diameter of the Earth, the apparent size in the sky being almost as large as that of the Sun, as a result, the Moon covers the Sun almost perfectly during total solar eclipses. This visual appearance match will not continue in the distant future, because the distance between the Moon and the Earth is slowly increasing.

The Soviet Union's Moon program was the first to reach the Moon with unmanned spacecraft in 1959; NASA's Apollo program in the United States has completed the only human missions to date, beginning with the first orbit of the moon by Apollo 8 in 1968 and continuing with six landings between 1969 and 1972, the first being the Apollo 11 mission. These missions brought lunar rock that was used to develop a 
geological understanding of the Moon's origin, its internal structure and more recent history. Since the Apollo 17 mission in 1972, the Moon has been visited only by unmanned spacecraft.

In human culture, both the natural prominence of the Moon in the Earth's sky and its regular phase cycle as it appears from Earth have provided cultural references and influences for human societies and cultures since time immemorial. Such cultural influences can be found in language, lunar calendar systems, art and mythology (Rulkov et al., 2016; Agarwala, 2016; Babayemi, 2016; Gusti and Semin, 2016; Mohamed et al., 2016; Wessels and Raad, 2016; Rajput et al., 2016; Rea and Ottaviano, 2016; Zurfi and Zhang, 2016a; 2016b; Zheng and Li, 2016; Buonomano et al., 2016a; 2016b; Faizal et al., 2016; Ascione et al., 2016; Elmeddahi et al., 2016; Calise et al., 2016; Morse et al., 2016; Abouobaida, 2016; Rohit and Dixit, 2016; Kazakov et al., 2016; Alwetaishi, 2016; Riccio et al., 2016a; 2016b; Iqbal, 2016; Hasan and El-Naas, 2016; Al-Hasan and Al-Ghamdi, 2016; Jiang et al., 2016; Sepúlveda, 2016; Martins et al., 2016; Pisello et al., 2016; Jarahi, 2016; Mondal et al., 2016; Mansour, 2016; Al Qadi et al., 2016b; Campo et al., 2016; Samantaray et al., 2016; Malomar et al., 2016; Rich and Badar, 2016; Hirun, 2016; Bucinell, 2016; Nabilou, 2016b; Barone et al., 2016; Chisari and Bedon, 2016; Bedon and Louter, 2016; dos Santos and Bedon, 2016; Minghini et al., 2016; Bedon, 2016; Jafari et al., 2016; Chiozzi et al., 2016; Orlando and Benvenuti, 2016; Wang and Yagi, 2016; Obaiys et al., 2016; Ahmed et al., 2016; Jauhari et al., 2016; Syahrullah and Sinaga, 2016; Shanmugam, 2016; Jaber and Bicker, 2016; Wang et al., 2016; Moubarek and Gharsallah, 2016; Amani, 2016; Shruti, 2016; Pérez-de León et al., 2016; Mohseni and Tsavdaridis, 2016; Abu-Lebdeh et al., 2016; Serebrennikov et al., 2016; Budak et al., 2016; Augustine et al., 2016; Jarahi and Seifilaleh, 2016; Nabilou, 2016a; You et al., 2016; AL Qadi et al., 2016a; Rama et al., 2016; Sallami et al., 2016; Huang et al., 2016; Ali et al., 2016; Kamble and Kumar, 2016; Saikia and Karak, 2016; Zeferino et al., 2016; Pravettoni et al., 2016; Bedon and Amadio, 2016; Chen and $\mathrm{Xu}, 2016$; Mavukkandy et al., 2016; Yeargin et al., 2016; Madani and Dababneh, 2016; Alhasanat et al., 2016; Elliott et al., 2016; Suarez et al., 2016; Kuli et al., 2016; Waters et al., 2016; Montgomery et al., 2016; Lamarre et al., 2016; Petrescu, 2012b; Aversa et al., 2017a; 2017b; 2016a; 2016b; 2016c; 2016d; 2016e; 2016f; 2016g; 2016h; 2016i; 2016j; 2016k; 2016l; 2016m; 2016n; 2016o; Petrescu and Petrescu, 2016; 2015a; 2015b; 2015c; 2015d; 2015e; 2014a; 2014b; 2014c; 2014d; 2014e; 2014f; 2014g; 2014h; 2014i; 2013a; 2013b; 2013c; 2013d; 2013e; 2013f; 2013g; 2012; 2011; 2005a; 2005b; 2005c; 2005d; 2005e; 2003; 2002a; 2002b; 2000a; 2000b; 1997a; 1997b; 1997c; 1995a; 1995b; Petrescu, 2018; 2015a; 2015b; 2012; Petrescu et al.,
2016; 2017a; 2017b; 2017c; 2017d; 2018a; 2018b; 2018c; 2018d; Petrescu and Calautit, 2016a; 2016b; Daud et al., 2008; Taher et al., 2008; Zulkifli et al., 2008; Pourmahmoud, 2008; Pannirselvam et al., 2008; $\mathrm{Ng}$ et al., 2008; El-Tous, 2008; Akhesmeh et al., 2008; Nachiengtai et al., 2008; Moezi et al., 2008; Boucetta, 2008; Darabi et al., 2008; Semin and Bakar, 2008; AlAbbas, 2009; Abdullah et al., 2009; Abu-Ein, 2009; Opafunso et al., 2009; Semin et al., 2009a; 2009b; 2009c; Zulkifli et al., 2009; Ab-Rahman et al., 2009; Abdullah and Halim, 2009; Zotos and Costopoulos, 2009; Feraga et al., 2009; Bakar et al., 2009; Cardu et al., 2009; Bolonkin, 2009a; 2009b; Nandhakumar et al., 2009; Odeh et al., 2009; Lubis et al., 2009; Fathallah and Bakar, 2009; Marghany and Hashim, 2009; Kwon et al., 2010; Aly and Abuelnasr, 2010; Farahani et al., 2010; Ahmed et al., 2010; Kunanoppadon, 2010; Helmy and El-Taweel, 2010; Qutbodin, 2010; Pattanasethanon, 2010; Fen et al., 2011; Thongwan et al., 2011; Theansuwan and Triratanasirichai, 2011; Al Smadi, 2011; Tourab et al., 2011; Raptis et al., 2011; Momani et al., 2011; Ismail et al., 2011; Anizan et al., 2011; Tsolakis and Raptis, 2011; Abdullah et al., 2011; Kechiche et al., 2011; Ho et al., 2011; Rajbhandari et al., 2011; Aleksic and Lovric, 2011; Kaewnai and Wongwises, 2011; Idarwazeh, 2011; Ebrahim et al., 2012; Abdelkrim et al., 2012; Mohan et al., 2012; Abam et al., 2012; Hassan et al., 2012; Jalil and Sampe, 2013; Jaoude and El-Tawil, 2013; Ali and Shumaker, 2013; Zhao, 2013; El-Labban et al., 2013; Djalel et al., 2013; Nahas and Kozaitis, 2014).

\section{Materials and Methods}

Several variants of mechanisms have been proposed that would have led to the formation of the Moon 4.51 billion years ago and about 60 million years after the origin of the Solar System. Among these mechanisms was the fission of the Moon from the Earth's crust, by centrifugal force (which would require too much initial kinetic moment of the Earth), the gravitational capture of a previously formed body (which would require the Earth's atmosphere too large to dissipate the energy of the passing body) and the formation of the Earth and the Moon together from the primordial accretion disk (which does not explain the lack of metals on the Moon). However, these hypotheses cannot explain the great kinetic moment of the Earth-Moon ensemble either.

The predominant hypothesis is that the Earth-Moon system formed as a result of the impact of a body the size of Mars (called Theia) with the proto-Earth (giant impact), which brought the material into Earth's orbit, which then gathered by gravity. to form the current Earth-Moon system.

The far side of the moon has a crust, $48 \mathrm{~km}$ thicker than that from Earth. It is believed that this is due to the fact that the Moon resulted from the amalgamation of two different bodies. 


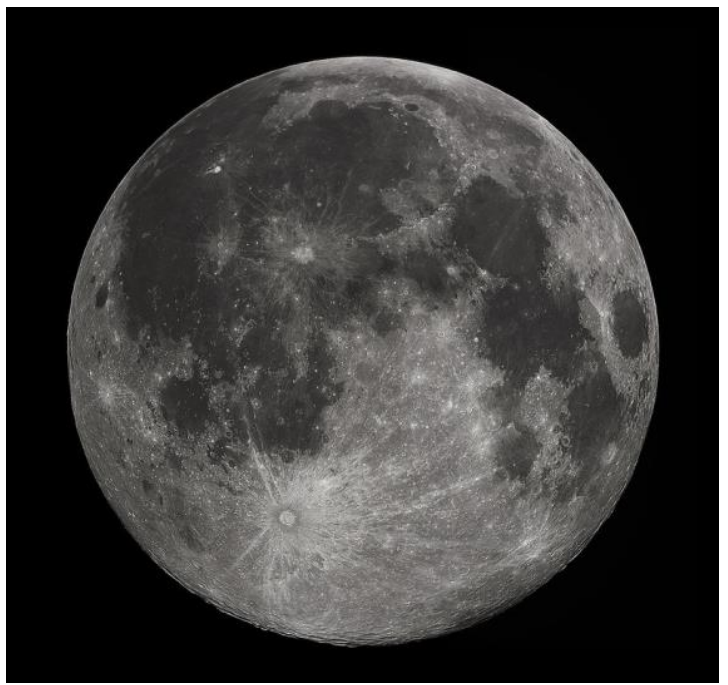

Fig. 1: Full Moon in the darkness of the night sky

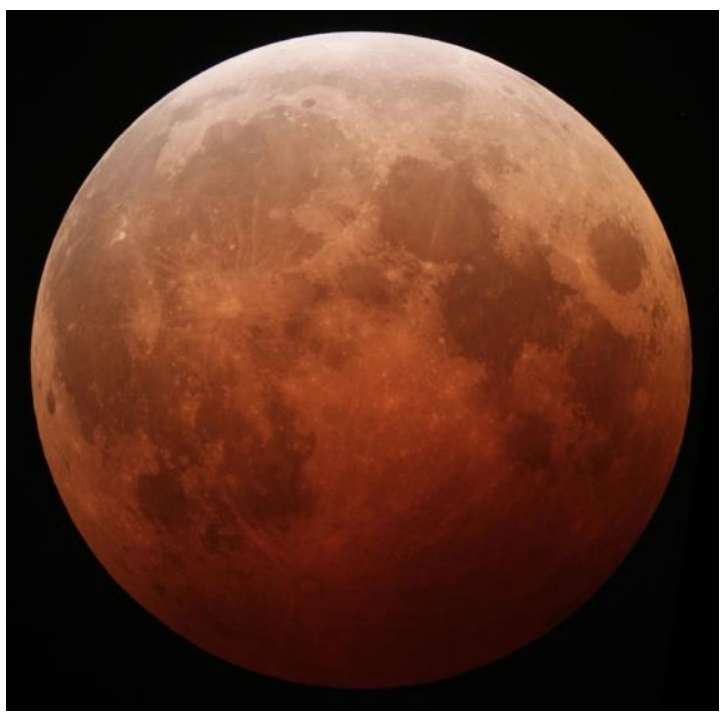

Fig. 2: The moon, colored in red, during a lunar eclipse

Full Moon in the darkness of the night sky. It is patterned with a mix of light-tone regions and darker, irregular blotches and scattered with varying sizes of impact craters, circles surrounded by out-thrown rays of bright ejecta (Fig. 1).

In the Fig. 2 can be seen the Moon, colored in red, during a lunar eclipse.

This hypothesis, although not perfect at all, probably best explains some of the evidence found. Eighteen months before a conference in October 1984 on the origins of the moon, Bill Hartmann, Roger Phillips and Jeff Taylor challenged fellow researchers on the moon: "You are eighteen months old. Go back to the Apollo data, go back to the computers, do whatever it takes, but make up your mind. Don't come to our conference if you don't have anything to say about the birth of the moon. " At the 1984 conference in Kona, Hawaii, the giant impact hypothesis became the most popular, but not the safest yet.

Before the conference, they were partisans of the three "traditional" hypotheses, plus a few who were beginning to take the giant impact seriously and among them was a large apathetic group that did not think any conclusion could be reached. After that, there were essentially only two groups left: The giant impact camp and the agnostics.

Giant impacts are thought to have been common in the early Solar System. Computer simulations of a giant impact produced results in accordance with the mass of the moon's core and the current kinetic moment of the Earth-Moon system. These simulations also show that much of the Moon resulted from the body with which the proto-Earth collided and not from the proto-Earth. More recent simulations suggest that a larger fraction of the Moon resulted from the initial mass of the Earth. The study of meteorites from bodies in the inner Solar System, such as Mars and Vesta, shows that they have very different compositions on oxygen and tungsten isotopes compared to Earth, while Earth and Moon have almost identical isotopic compositions. The isotopic equalization of the EarthMoon system could be explained by the post-impact mixing of the vaporized materials that formed the two, although this hypothesis is still being discussed.

The large amount of energy released from the impact and subsequent re-accretion of those materials in the Earth-Moon system would have melted the Earth's outer shell, forming an ocean of magma. Similarly, the newly formed Moon would have been affected and had its own lunar ocean of magma; its depth estimates range from about $500 \mathrm{~km}$ to its entire depth $(1,737 \mathrm{~km})$.

While the gigantic impact hypothesis would explain many lines of evidence, there are still some unresolved issues, most of which involve the composition of the Moon.

In 2001, a team at the Carnegie Institution in Washington reported the most accurate measurement of the isotopic signatures of lunar rocks. To their surprise, the team found that the rocks in the Apollo program bore an isotopic footprint identical to the rocks on Earth and that they were different from almost every other body in the Solar System. Because much of the material that went into orbit to form the Moon was thought to have come from Theia, this observation was unexpected. In 2007, researchers at the California Institute of Technology announced that there was less than a $1 \%$ chance that Theia and Earth had identical isotopic signatures. Published in 2012, an analysis of titanium isotopes from samples collected from the Moon by the Apollo mission showed that the Moon has the same composition as Earth (Astrobiology Magazine, 2012), which contradicts what was expected if the Moon -would 
have formed far from Earth's orbit or Theia. Variations in the giant impact hypothesis may explain these data.

The moon is a differentiated body: It has a geochemically distinct crust, mantle and core. The moon has an inner core rich in iron with a radius of 240 kilometers (150 mi) and an outer core liquid, mainly made of liquid iron, with a radius of about $300 \mathrm{~km}$. Around the core is a partially melted boundary layer with a radius of about $500 \mathrm{~km}$. This structure is thought to have developed through the fractional crystallization of a global ocean of magma shortly after the Moon formed 4.5 billion years ago. The crystallization of this ocean of magma would have created a mafic mantle from the precipitation and sinking of the minerals olivine, clinopyroxene and orthopyroxene; after about threequarters of the ocean's magma crystallized, smallerdensity plagioclase minerals would have formed, which floated above, forming a crust. The last liquids that crystallized were initially trapped between the crust and the mantle, with a large abundance of incompatible and heat-producing elements. Consistent with this view, geochemical mapping made from orbit suggests that the crust is mostly an orthotic. The monthly rock samples of the lavas that erupted on the surface from the partial melting in the mantle confirm the mafic composition of the mantle, which is much richer in iron than that of the Earth. The bark is, on average, about 50 kilometers thick.

The moon is the second densest satellite in the Solar System, after Io. However, the inner core of the Moon is small, with a radius of about 350 kilometers or less, about $20 \%$ of the Moon's radius. Its composition is not well defined, but it is probably metallic iron alloyed with a small amount of sulfur and nickel; analyzes of the Moon's time-varying rotation suggest that it is at least partially melted (Williams et al., 2006).

NASA specialists are beginning to present the amazing results of older space missions and experiments conducted on the surface of the Earth's natural satellite.

During Apollo space missions, over time, 14 astronauts conducted research and experiments on the surface of the Moon in the field of seismology, writes an article posted on Friday on the official website of NASA.

Renne Weber, the coordinator of the research team at NASA's Marshall Space Flight Center in Huntsville, Alabama, said that "using modern techniques and data from previous space missions, (we can say that) the Moon has a core similar to that of Earth ".

American specialists processed the data collected during the selenium missions, carried out between 19691972, when 4 seismometers were placed, which recorded the activity of the month until the end of 1977.

At the same time, another team of scientists from Arizona State University, the University of California at Santa Cruz and the Institute of Earth Physics in Paris, France, published their findings in the online edition of the journal Science.

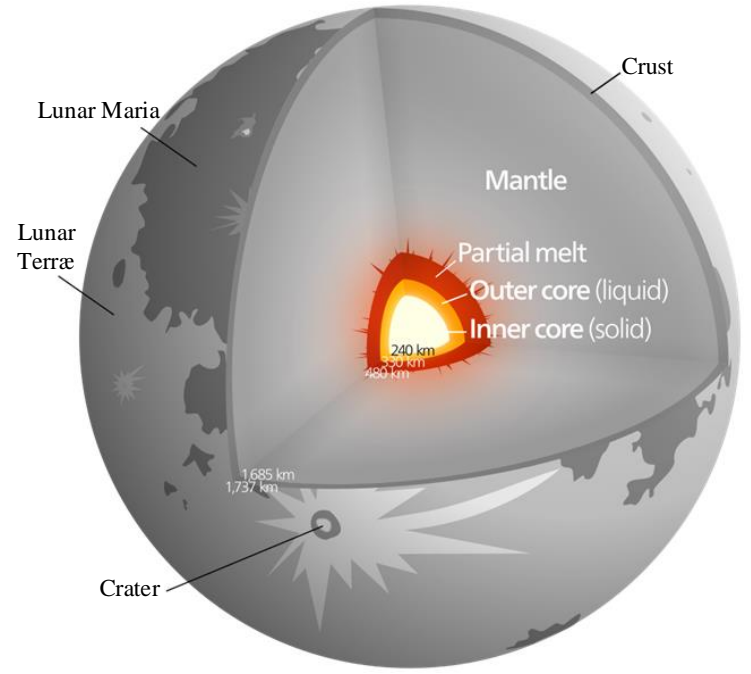

Fig. 3: Structure of the Moon

Also this year, NASA, together with experts from Germany, will launch a new GRAIL space mission, which involves launching space probes, which will enter in tandem in an orbit around the Moon, for detailed measurements of the star's gravitational field.

Figure 3 shows the structure of the Moon.

NASA is planning another mission to the Moon, called Gravity, with a module for recovering seismometers.

Moreover, together with the other space agencies, NASA is launching a new large-scale project, the Lunar International Network, which consists of placing geophysical monitoring stations on the Moon's surface (Fig. 4).

More similarities begin to appear between the Moon and the Earth that bring them closer even than we expect in the sense that it is increasingly difficult to think even of the theory of the Moon breaking from the Earth, after which it formed its own structure similar to the Earth in which came off.

The topography of the Moon was measured with laser altimetry and stereo image analysis. The most visible topographic features are the huge South Pole - Aitken basin on the hidden face, about $2,240 \mathrm{~km}$ in diameter, the largest crater on the Moon and the second largest confirmed impact crater in the Solar System.

At a depth of $13 \mathrm{~km}$, its bottom is the lowest point on the Moon's surface. The highest altitudes on the Moon's surface are located directly to the northeast and it has been suggested that they may have been thickened by the oblique impact that led to the formation of the South Pole - Aitken Basin. Other large impact basins, such as Imbrium, Serenitatis, Crisium, Smythii and Orientale, also have low altitudes and high regional edges. The hidden part of the lunar surface is, on average, about 1.9 kilometers higher than the visible one. 


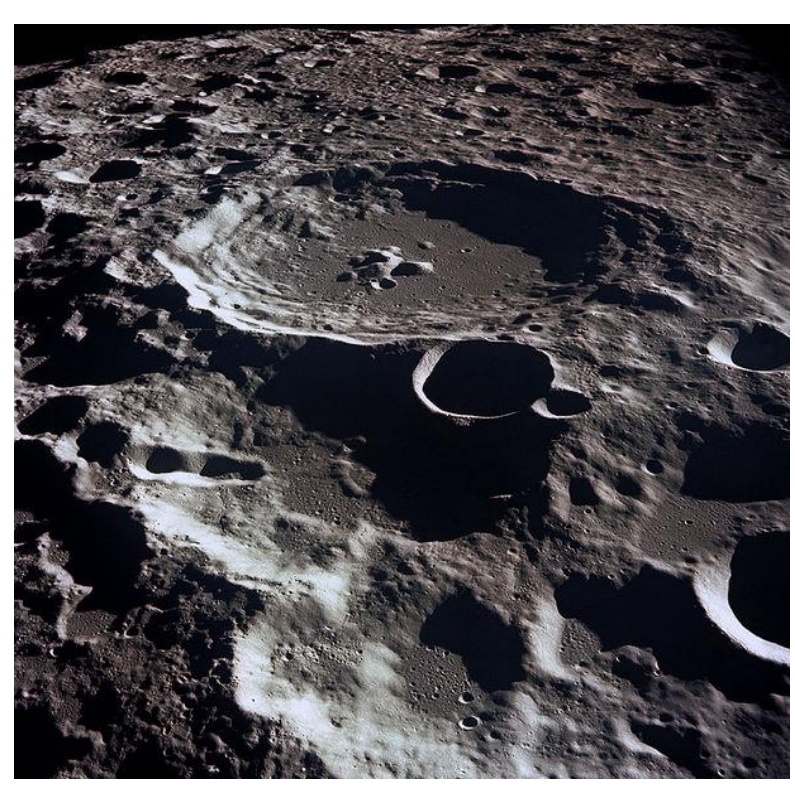

Fig. 4: NASA makes new revelations about the internal structure of the Moon. The lunar crater Daedalus on the hidden hemisphere of the Moon

The discovery of fault slopes by the Lunar Reconnaissance Orbiter suggests that the Moon has shrunk in the last billion years, by about $90 \mathrm{~m}$. Similar features of contraction exist on Mercury.

The darker monthly plains and relatively devoid of features clearly visible to the naked eye, are called seas, as they were once thought to be full of water; it is now known that there are vast basins of solidified basaltic lava. Although similar to terrestrial basalts, lunar basalts have more iron and lack modified water minerals. most of these lavas erupted or flowed into depressions associated with impact craters. Several geological provinces containing shield volcanoes and volcanic domes are located near the seas in the visible hemisphere.

Almost all seas are on the visible side of the Moon and cover $31 \%$ of the surface of this hemisphere, compared to $2 \%$ of the hidden hemisphere. It is considered to be caused by the concentration of heatproducing elements under the visible crust, seen on the geochemical maps obtained by Lunar Prospector's gamma-ray spectrometer, which would have heated the mantle below, melting it. partial, raising it to the surface and erupting. Most of the moon's marine basalts erupted in the Imbrian period, about 3-3.5 billion years ago, although some radiometrically dated evidence is even 4.2 billion years old. Until recently, the oldest eruptions, dated by counting craters, appear to have been only 1.2 billion years ago. In 2006, a study of the Ina crater, a small depression in Lacus Felicitatis, found some sharp, relatively dust-free landforms that, due to the lack of erosion propagated by falling materials, appeared to be only 2 million years. Monthly earthquakes and gas emissions also indicate continued activity on the Moon. In 2014, NASA announced "widespread evidence of young lunar volcanism" in 70 irregular sea portions identified by the Lunar Reconnaissance Orbiter, some less than 50 million years old. This raises the possibility that the lunar mantle is much warmer than previously thought, at least in the near hemisphere, where the deep crust is substantially warmer due to a higher concentration of radioactive elements. Shortly before that, evidence was presented of a 2-10 million-year-old basaltic volcanism inside Lowell Crater, the East Sea, located in the transition zone between the visible and hidden hemispheres of the Moon. An initially warmer mantle and/or a local enrichment of the heat-producing elements in the mantle could be responsible for a longer duration of these activities and in the remote part of the East Sea.

The lighter regions of the moon are called terrae, or more commonly mountains because they are higher than most seas. Radiometric dating indicates an age of 4.4 billion years and may represent plagioclase "accumulated" from the lunar ocean of magma. Unlike the Earth, it is believed that no large mountains formed on the Moon as a result of tectonic events.

The concentration of seas in the visible hemisphere probably reflects the substantially thicker crust of the mountains of the hidden hemisphere, which may have formed in a low-speed impact with a second satellite of the Earth several tens of millions of years after their formation.

The other important geological process that has affected the moon's surface are impact craters, craters formed when asteroids and comets collide with the moon's surface. The Moon is estimated to have about 300,000 craters larger than $1 \mathrm{~km}$ on the visible face of the Moon alone. The monthly geological scale is based on the most important impact events, including Nectaris, Imbrium and Orientale, structures characterized by several rings of raised material, with diameters between hundreds and thousands of kilometers and associated with a wide belt of deposits of ejected materials that form a regional stratigraphic horizon. The lack of an atmosphere, its associated erosion factors and the lack of recent geological processes mean that many of these craters are well preserved. Although only a few multiring basins have been accurately dated, they are useful for assigning those geological eras. Because impact craters accumulate at an almost constant rate, the number of craters per unit area can be used to estimate the age of the surface. The radiometric ages of the impact-melted rocks collected during the Apollo missions are mainly between 3.8 and 4.1 billion years: Based on this information, the hypothesis of a large late bombardment was launched. 


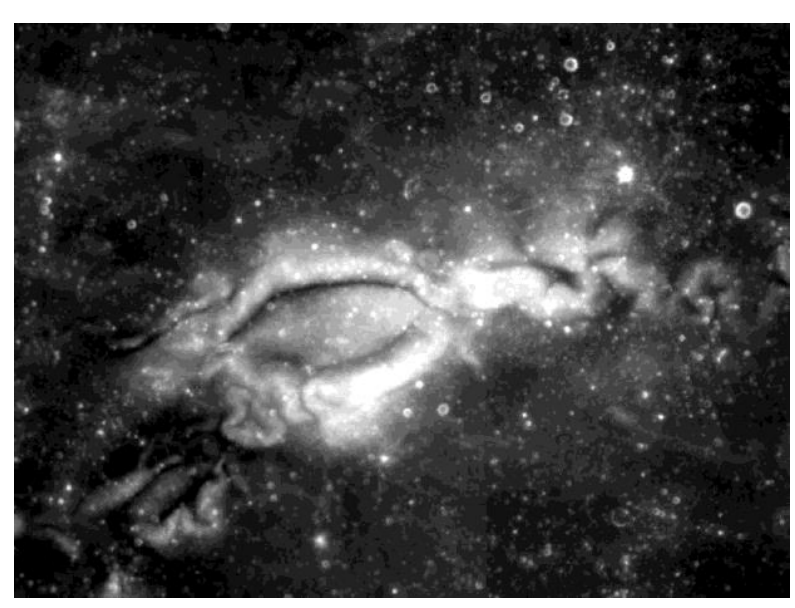

Fig. 5: Monthly vortices in Reiner Gamma

On the upper part of the crust of the Moon is an extremely crushed rock layer (broken into smaller particles) and impact-processed, called regolith, shaped by impact processes. The finest regolith, lunar soil made of silicon dioxide glass, has a snow-like texture and a smell like burnt gunpowder. The rule on older surfaces is generally thicker than on younger surfaces: It varies in thickness from 10-20 kilometers in the mountains to 3-5 kilometers in the seas. Beneath the finely chopped regolith is the megaregolite, a layer of strongly fractured stone many kilometers thick.

A comparison of the high-resolution images obtained by the Lunar Reconnaissance Orbiter revealed a significantly higher contemporary crater production rate than previously estimated. It is believed that a secondary process of crater formation caused by distal ejected materials disturbs the first two centimeters of regolith a hundred times faster than previous models - over a period of 81,000 years.

Lunar vortices are enigmatic landforms found on the surface of the Moon, which is characterized by a large albedo, which appears optically immature (i.e., have the optical characteristics of a relatively young regolith) and often have a sinuous shape. Their curvilinear shape is often accentuated by the low albedo regions that meander around the bright vortices (Fig. 5).

\section{Results}

Liquid water cannot persist on the surface of the Moon. When exposed to solar radiation, water decomposes rapidly through a process known as photodissociation and is lost in space. However, since the 1960s, scientists have hypothesized that ice may be deposited by the impact of comets or possibly a reaction product between oxygen-rich lunar rocks and hydrogen from the solar wind, leaving traces of water that could survive in the cold places of the permanently shaded craters at the poles of the Moon. Computer simulations suggest that up to $14,000 \mathrm{~km}^{2}$ of the surface could be in permanent shade. The presence of useful amounts of water on the Moon is an important factor in making the colonization of the Moon a feasible plan in terms of costs; the alternative of transporting water from Earth would have a prohibitive cost.

Later, traces of water were found on the surface of the Moon. In 1994, the bistatic radar experiment on the Clementine spacecraft indicated the existence of small, frozen pockets of water near the surface. Subsequent radar observations by Arecibo suggest, however, that these discoveries are rather rocks ejected from recent impact craters. In 1998, the Lunar Prospector spacecraft's neutron spectrometer showed that high concentrations of hydrogen were present in the first meter deep of the regolith near the polar regions. Volcanic lava balls brought to Earth aboard the Apollo 15 spacecraft have small amounts of water inside them (Saal et al., 2008).

The Chandrayaan-1 spacecraft launched in 2008 later confirmed the existence of surface water with its Moon Mineralogy Mapper tool. The spectrometer observed lines of absorption common to the hydroxyl radical in reflected sunlight, which is an indication of the presence of large amounts of ice on the surface of the Moon. It has been shown that concentrations could even reach $1000 \mathrm{ppm}$. In 2009, LCROSS sent an impact object with a mass of $2,300 \mathrm{~kg}$ into a permanently shaded polar crater and detected at least $100 \mathrm{~kg}$ of water in a column of ejected materials. Another examination of the LCROSS data showed that the detected water could be rather $155 \pm 12 \mathrm{~kg}$.

In May 2011, 615-1410 ppm of water was reported embedded in the monthly sample 74220, the famous "orange glassy soil" rich in titanium, of volcanic origin, brought by the Apollo 17 mission in 1972. These were formed during some explosive eruptions on the moon about 3.7 billion years ago. This concentration is comparable to that of magma in the Earth's upper mantle. Although of considerable selenological interest, this announcement does not comfort the Moon's colonization enthusiasts - the sample comes from a depth of many kilometers and the substance is so difficult to access that it was found only after 39 years, with a sophisticated tool. ion microextraction.

The gravitational field of the Moon was measured by tracking the Doppler displacement of radio signals emitted by a spacecraft from orbit. The monthly gravity shows large positive gravitational anomalies associated with some of the impact craters, produced in part by the denser flow of basaltic lava from the seas that fills these craters. The anomalies greatly influence the orbit of the ships around the Moon. There are also some riddles: The lava flow alone cannot explain the entire gravitational signature and there are masks that are not related to volcanism in the seas. 


\section{Discussion}

Decades after launching the first and last man on the moon, NASA plans to build the lunar orbital platform in the 2020s.

As reflected in NASA's Exploration Campaign, the next step in manned spaceflight is to establish a US presence in space by deploying a lunar orbital platform - LOP-G, according to an agency statement. Together with the Space Launch System (SLS) and Orion, the lunar station or "gate" is essential for advancing and sustaining manned space exploration goals and is the unifying point of our architecture for human lunar operations, lunar surface access and missions. on Mars, according to the quoted source.

"I think it's a big step for us and for everyone. Now you can see that things are getting very, very serious. The White House is very supportive of the initiative and we spent a few years talking about it and dreaming of a concept and now it's finally happening, "said Philippe Schoonejans, head of the robotics and future projects department and coordinator for ESA's Meteron project. The LOP-G will be like a space station in orbit around the moon and is planned to be ready for human hosting by 2023. The platform will consist of at least one element of power and propulsion, habitability, logistics and docking possibilities. To be assembled in space in time (like the International Space Station or ISS), the first module will be a power and propulsion system, which is destined for launch in 2022.

It will use "high power electric propulsion" to maintain the position of the platform in a stable lunar orbit but also for changes in orbit, closer or farther from the Moon, depending on scientific and exploratory objectives. Another capability of this module will allow it to function as a high-tech communications platform to transmit between Earth, space, moon and other spacecraft, as well as to transfer large amounts of data using lasers.

Currently, five companies are completing their studies, as part of NASA's public-private partnership, to develop this power and propulsion module in an affordable way.

The space agency is also considering partnerships for other elements of the gateway, such as logistics, airlocks and housing modules. Launching elements into space for assembly could be done using NASA's future Space Launch System and Orion spacecraft or commercial rockets.

The human habitation module will be launched in 2023 if everything goes according to plan. While the partnership with private companies will require them to be informed about some of the capabilities of this module, for possible cooperation, it will also benefit from the knowledge already gained from using the ISS and its partners at the International Station. This module would allow the station crew to live and work in deep space for 30-60 days on a mission.

The docking and access module outside the lunar station will allow the crew to travel in space and also attach future elements that will become part of the gateway. Power missions through the access gate will be made using commercial spacecraft.

The team onboard the platform will undertake scientific, commercial and exploratory activities not only around the Moon but also on the lunar surface. NASA will also work on developing increasingly complex robotic missions, which will be carried out on the surface of the moon before a human crew goes there. The LOP$\mathrm{G}$ could be placed in what scientists call an almost Rectilinear Halo Orbit (NRHO), an orbit in space that could serve as a waiting area for future missions.

Such orbits, which pass close to the moon and then loop far away from the satellite, have the advantage of being close to the moon, but always keep the station in line with the flight controllers on Earth, as well as in sunlight for solar panels.

The station's unique point of view will allow astronauts to operate telerobots on the lunar surface, said Harley Thronson, a senior technologist at NASA's Goddard Space Flight Center in Greenbelt, Maryland.

This could include exploring the youngest craters on the moon or arranging radio antennas to examine hydrogen-generated radio emissions when the universe was very young, he said.

"The earth itself could become a target for LOP-G observation," Thronson said. "Inexplicably, there have been very few space observations of the entire Earth that repeat exactly how Earth-like planets could appear in future astronomical observatories." The platform should be in orbit on the moon by 2025, said Gerstenmaier, a NASA veteran who oversees human exploration and operations.

Lunar Orbital Platform-Gateway has also received numerous criticisms from several space professionals who claim, more or less elegantly, that the objective does not have a true scientific purpose (Fig. 6).

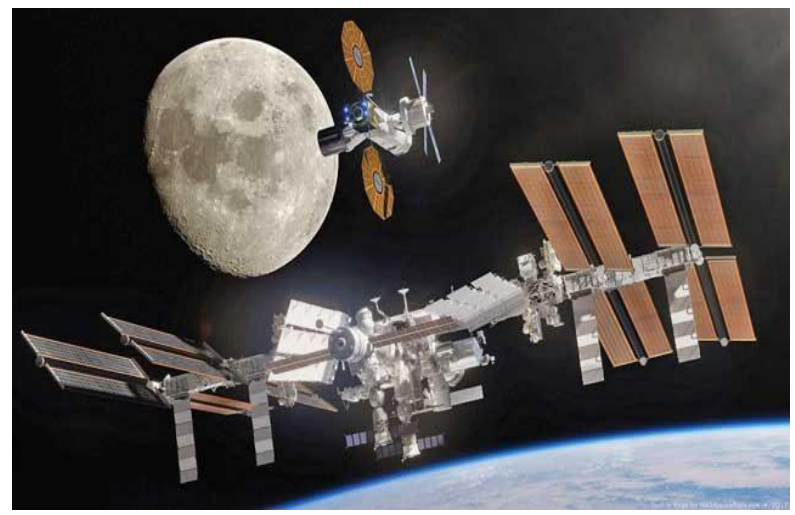

Fig. 6: Lunar Orbital Platform-Gateway 


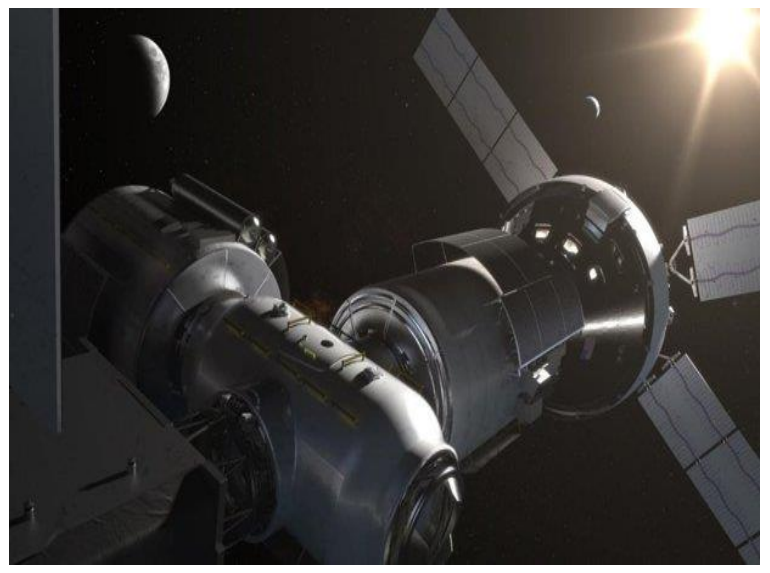

Fig. 7: NASA plans to launch Gateway in 2023

The Gateway platform is an important part of NASA's long-term space exploration plans.

The Gateway platform was considered fundamental to a new landing on the Artemis program, however, due to problems with some delays it was removed from NASA's plans. However, Ars Technica notes that the agency's current plans provide for the core of this platform to be launched in 2023.

Doug Loverro, director of NASA's manned flight program, said the first two elements of the platform will be launched together and that means the elements that provide power and propulsion and habitat, produced by Maxar and Northrop Grumman, respectively. they will be assembled on the ground and will be launched with the help of a private rocket.

Experts explain that federal law requires such a contract to be put up for auction, however, NASA has calculated the size and mass of these items that would be launched so that they could be transported by Falcon Heavy, one of the most powerful. missiles from the commercial space fleet. "We made sure that it could be done (n.r. launch) with Falcon Heavy," Loverro said. "We have not yet selected the launch vehicle, but we had to make sure that there will be at least one vehicle for it. And that's how we know Falcon Heavy can do it and we know that because it has to meet the requirements of the Department of Air Force Defense for an extended core. So there could be several options, but we had to check at least one ", he adds.

Most likely, the core elements of the Gateway will be assembled in the second half of this year, stating that the achievement of this goal depends on a multitude of factors (Fig. 7).

\section{Conclusion}

It seems that the time has finally come when we will begin the careful exploration and surveillance of the Moon, our natural satellite that has been orbiting the Earth for billions of years.
The Gateway orbital space station, which is meant to rotate around the Moon, will finally be built, transported into space and finally assembled to begin its humanitarian mission of rotating around the Moon and to constantly monitor it in order to obtain important new data on features more secret of the Moon, the natural satellite of the Earth which we want to colonize in the near future starting with the construction of human bases on the Moon.

\section{Acknowledgement}

The work was appreciated by teams of professors from the departments of automobiles from several universities in Romania and Italy. This text was acknowledged and appreciated by Associate Professor Aniello Riccio SECONDA UNIVERSITA’ DEGLI STUDI DI NAPOLI Italy, whom we thanks and in this way.

\section{Funding Information}

Research contract: Contract number 36-5-4D/1986 from 24IV1985, beneficiary CNST RO (Romanian National Center for Science and Technology) Improving dynamic mechanisms internal combustion engines. All these matters are copyrighted. Copyrights: 548cgiywDssin, from: 22-04-2010, 08:48:48.

\section{Author's Contributions}

All the authors contributed equally to prepare, develop and carry out this manuscript.

\section{Ethics}

Author declares that are not ethical issues that may arise after the publication of this manuscript. This article is original and contains unpublished material.

\section{References}

Ab-Rahman, M.S., H. Guna, M.H. Harun, S.D. Zan and K. Jumari, 2009. Cost-effective fabrication of selfmade $1 \times 12$ polymer optical fiber-based optical splitters for automotive application. Am. J. Eng. Applied Sci., 2: 252-259.

DOI: 10.3844/ajeassp.2009.252.259

Abam, F.I., I.U. Ugot and D.I. Igbong, 2012. Performance analysis and components irreversibilities of a $(25$ MW) gas turbine power plant modeled with a spray cooler. Am. J. Eng. Applied Sci., 5: 35-41.

DOI: 10.3844/ajeassp.2012.35.41

Abdelkrim, H., S.B. Othman, A.K.B. Salem and S.B. Saoud, 2012. Dynamic partial reconfiguration contribution on system on programmable chip architecture for motor drive implementation. Am. J. Eng. Applied Sci., 5: 15-24.

DOI: 10.3844/ajeassp.2012.15.24 
Abdullah, M.Z., A. Saat and Z. Hamzah, 2011. Optimization of energy dispersive x-ray fluorescence spectrometer to analyze heavy metals in moss samples. Am. J. Eng. Applied Sci., 4: 355-362. DOI: 10.3844/ajeassp.2011.355.362

Abdullah, M., A.F.M. Zain, Y.H. Ho and S. Abdullah, 2009. TEC and scintillation study of equatorial ionosphere: A month campaign over sipitang and parit raja stations, Malaysia. Am. J. Eng. Applied Sci., 2: 44-49. DOI: 10.3844/ajeassp.2009.44.49

Abdullah, H. and S.A. Halim, 2009. Electrical and magnetoresistive studies $\mathrm{Nd}$ doped on La-Ba-Mn- $\mathrm{O}_{3}$ manganites for low-field sensor application. Am. J. Eng. Applied Sci., 2: 297-303.

DOI: 10.3844/ajeassp.2009.297.303

Abouobaida, H., 2016. Robust and efficient controller to design a standalone source supplied DC and AC load powered by photovoltaic generator. Am. J. Eng. Applied Sci., 9: 894-901.

DOI: 10.3844/ajeassp.2016.894.901

Abu-Ein, S., 2009. Numerical and analytical study of exhaust gases flow in porous media with applications to diesel particulate filters. Am. J. Eng. Applied Sci., 2: 70-75. DOI: 10.3844/ajeassp.2009.70.75

Abu-Lebdeh, T.M., G. Pérez-de León, S.A. Hamoush, R.D. Seals and V.E. Lamberti, 2016. Gas atomization of molten metal: Part II. Applications. Am. J. Eng. Applied Sci., 9: 334-349.

DOI: 10.3844/ajeassp.2016.334.349

Agarwala, S., 2016. A perspective on 3D bioprinting technology: Present and future. Am. J. Eng. Applied Sci., 9: 985-990.

DOI: 10.3844/ajeassp.2016.985.990

Ahmed, M., R. Khan, M. Billah and S. Farhana, 2010. A novel navigation algorithm for hexagonal hexapod robot. Am. J. Eng. Applied Sci., 3: 320-327. DOI: 10.3844/ajeassp.2010.320.327

Ahmed, R., M. Khan, H. Haque and H. Rahman, 2016. An approach to develop a dynamic job shop scheduling by fuzzy rule-based system and comparative study with the traditional priority rules. Am. J. Eng. Applied Sci., 9: 202-212.

DOI: 10.3844/ajeassp.2016.202.212

Akhesmeh, S., N. Pourmahmoud and H. Sedgi, 2008. Numerical study of the temperature separation in the ranque-hilsch vortex tube. Am. J. Eng. Applied Sci., 1: 181-187. DOI: 10.3844/ajeassp.2008.181.187

Al-Abbas, I.K., 2009. Reduced order models of a current source inverter induction motor drive. Am. J. Eng. Applied Sci., 2: 39-43.

DOI: 10.3844/ajeassp.2009.39.43

Al-Hasan, M.I. and A.S. Al-Ghamdi, 2016. Energy balance for a diesel engine operates on a pure biodiesel, diesel fuel and biodiesel-diesel blends. Am. J. Eng. Applied Sci., 9: 458-465.

DOI: 10.3844/ajeassp.2016.458.465
Al Smadi, T.A., 2011. Low cost smart sensor design. Am. J. Eng. Applied Sci., 4: 162-168. DOI: 10.3844/ajeassp.2011.162.168

Al Qadi, A.N.S., M.B.A. ALhasanat, A. Al Dahamsheh and S. Al Zaiydneen, 2016a. Using of box-benken method to predict the compressive strength of selfcompacting concrete containing Wadi Musa Bentonite, Jordan. Am. J. Eng. Applied Sci., 9: 406-411. DOI: 10.3844/ajeassp.2016.406.411

Al Qadi, A.N.S., M.B.A. Alhasanat and M. Haddad, 2016b. Effect of crumb rubber as coarse and fine aggregates on the properties of asphalt concrete. Am. J. Eng. Applied Sci., 9: 558-564.

DOI: 10.3844/ajeassp.2016.558.564

Aleksic, S. and A. Lovric, 2011. Energy consumption and environmental implications of wired access networks. Am. J. Eng. Applied Sci., 4: 531-539. DOI: 10.3844/ajeassp.2011.531.539

Alhasanat, M.B., A.N. Al Qadi, O.A. Al Khashman and A. Dahamsheh, 2016. Scanning electron microscopic evaluation of self-compacting concrete spalling at elevated temperatures. Am. J. Eng. Applied Sci., 9: 119-127. DOI: 10.3844/ajeassp.2016.119.127

Ali, K.S. and J.L. Shumaker, 2013. Hardware in the loop simulator for multi-agent unmanned aerial vehicles environment. Am. J. Eng. Applied Sci., 6: 172-177. DOI: 10.3844/ajeassp.2013.172.177

Ali, G.A.M., O. Fouad and S.A. Makhlouf, 2016. Electrical properties of cobalt oxide/silica nanocomposites obtained by sol-gel technique. Am. J. Eng. Applied Sci., 9: 12-16. DOI: 10.3844/ajeassp.2016.12.16

Alwetaishi, M.S., 2016. Impact of building function on thermal comfort: A review paper. Am. J. Eng. Applied Sci., 9: 928-945. DOI: 10.3844/ajeassp.2016.928.945

Aly, W.M. and M.S. Abuelnasr, 2010. Electronic design automation using object oriented electronics. Am. J. Eng. Applied Sci., 3: 121-127.

DOI: 10.3844/ajeassp.2010.121.127

Amani, N., 2016. Design and implementation of optimum management system using cost evaluation and financial analysis for prevention of building failure. Am. J. Eng. Applied Sci., 9: 281-296. DOI: 10.3844/ajeassp.2016.281.296

Anizan, S., K. Yusri, C.S. Leong, N. Amin and S. Zaidi et al., 2011. Effects of the contact resistivity variations of the screen-printed silicon solar cell. Am. J. Eng. Applied Sci., 4: 328-331. DOI: 10.3844/ajeassp.2011.328.331

Ascione, F., N. Bianco, R.F. De Masi, F. de Rossi and C. De Stasio et al., 2016. Energy audit of health care facilities: Dynamic simulation of energy performances and energy-oriented refurbishment of system and equipment for microclimatic control. Am. J. Eng. Applied Sci., 9: 814-834. DOI: 10.3844/ajeassp.2016.814.834 
Astrobiology Magazine, 2012. Titanium paternity test says earth is the moon's only parent. University of Chicago.

Augustine, A., R.D. Prakash, R. Xavier and M.C. Parassery, 2016. Review of signal processing techniques for detection of power quality events. Am. J. Eng. Applied Sci., 9: 364-370.

DOI: 10.3844/ajeassp.2016.364.370

Aversa, R., R.V.V. Petrescu, A. Apicella and F.I.T. Petrescu, 2017a. Nano-diamond hybrid materials for structural biomedical application. Am. J. Biochem. Biotechnol., 13: 34-41.

DOI: $10.3844 / a j b b s p .2017 .34 .41$

Aversa, R., D. Parcesepe, R.V.V. Petrescu, F. Berto and G. Chen et al., 2017b. Process ability of bulk metallic glasses. Am. J. Applied Sci., 14: 294-301. DOI: 10.3844/ajassp.2017.294.301

Aversa, R., F.I.T. Petrescu, R.V. Petrescu and A. Apicella, 2016a. Biomimetic FEA bone modeling for customized hybrid biological prostheses development. Am. J. Applied Sci., 13: 1060-1067. DOI: 10.3844/ajassp.2016.1060.1067

Aversa, R., D. Parcesepe, R.V. Petrescu, G. Chen and F.I.T. Petrescu et al., 2016b. Glassy amorphous metal injection molded induced morphological defects. Am. J. Applied Sci., 13: 1476-1482.

DOI: 10.3844 /ajassp.2016.1476.1482

Aversa, R., R.V. Petrescu, F.I.T. Petrescu and A. Apicella, 2016c. Smart-factory: Optimization and process control of composite centrifuged pipes. Am. J. Applied Sci., 13: 1330-1341.

DOI: 10.3844/ajassp.2016.1330.1341

Aversa, R., F. Tamburrino, R.V. Petrescu, F.I.T. Petrescu and M. Artur et al., 2016d. Biomechanically inspired shape memory effect machines driven by muscle like acting NiTi alloys. Am. J. Applied Sci., 13: 1264-1271.

DOI: 10.3844/ajassp.2016.1264.1271

Aversa, R., E.M. Buzea, R.V. Petrescu, A. Apicella and M. Neacsa et al., 2016e. Present a mechatronic system having able to determine the concentration of carotenoids. Am. J. Eng. Applied Sci., 9: 1106-1111. DOI: 10.3844/ajeassp.2016.1106.1111

Aversa, R., R.V. Petrescu, R. Sorrentino, F.I.T. Petrescu and A. Apicella, 2016f. Hybrid ceramo-polymeric nanocomposite for biomimetic scaffolds design and preparation. Am. J. Eng. Applied Sci., 9: 1096-1105. DOI: 10.3844/ajeassp.2016.1096.1105

Aversa, R., V. Perrotta, R.V. Petrescu, C. Misiano and F.I.T. Petrescu et al., 2016g. From structural colors to super-hydrophobicity and achromatic transparent protective coatings: Ion plating plasma assisted $\mathrm{TiO}_{2}$ and $\mathrm{SiO}_{2}$ Nano-film deposition. Am. J. Eng. Applied Sci., 9: 1037-1045.

DOI: 10.3844/ajeassp.2016.1037.1045
Aversa, R., R.V. Petrescu, F.I.T. Petrescu and A. Apicella, 2016h. Biomimetic and evolutionary design driven innovation in sustainable products development. Am. J. Eng. Applied Sci., 9: 1027-1036. DOI: 10.3844/ajeassp.2016.1027.1036

Aversa, R., R.V. Petrescu, A. Apicella and F.I.T. Petrescu, 2016i. Mitochondria are naturally micro robots-a review. Am. J. Eng. Applied Sci., 9: 991-1002.

Aversa, R., R.V. Petrescu, A. Apicella and F.I.T. Petrescu, 2016j. We are addicted to vitamins $\mathrm{C}$ and E-A review. Am. J. Eng. Applied Sci., 9: 1003-1018. DOI: 10.3844/ajeassp.2016.1003.1018

Aversa, R., R.V. Petrescu, A. Apicella and F.I.T. Petrescu, 2016k. Physiologic human fluids and swelling behavior of hydrophilic biocompatible hybrid ceramo-polymeric materials. Am. J. Eng. Applied Sci., 9: 962-972.

DOI: 10.3844/ajeassp.2016.962.972

Aversa, R., R.V. Petrescu, A. Apicella and F.I.T. Petrescu, 20161. One can slow down the aging through antioxidants. Am. J. Eng. Applied Sci., 9: 1112-1126. DOI: 10.3844/ajeassp.2016.1112.1126

Aversa, R., R.V. Petrescu, A. Apicella and F.I.T. Petrescu, 2016m. About homeopathy or «Similia similibus curentur $\gg$. Am. J. Eng. Applied Sci., 9: 1164-1172. DOI: 10.3844/ajeassp.2016.1164.1172

Aversa, R., R.V. Petrescu, A. Apicella and F.I.T. Petrescu, 2016n. The basic elements of life's. Am. J. Eng. Applied Sci., 9: 1189-1197.

DOI: 10.3844/ajeassp.2016.1189.1197

Aversa, R., F.I.T. Petrescu, R.V. Petrescu and A. Apicella, 2016o. Flexible stem trabecular prostheses. Am. J. Eng. Applied Sci., 9: 1213-1221. DOI: 10.3844/ajeassp.2016.1213.1221

Babayemi, A.K., 2016. Thermodynamics, non-linear isotherms, statistical modeling and optimization of phosphorus adsorption from wastewater. Am. J. Eng. Applied Sci., 9: 1019-1026.

DOI: 10.3844/ajeassp.2016.1019.1026

Bakar, R.A., M.K. Mohammed and M.M. Rahman, 2009. Numerical study on the performance characteristics of hydrogen fueled port injection internal combustion engine. Am. J. Eng. Applied Sci., 2: 407-415. DOI: 10.3844/ajeassp.2009.407.415

Barone, G., A. Buonomano, C. Forzano and A. Palombo, 2016. WLHP systems in commercial buildings: A case study analysis based on a dynamic simulation approach. Am. J. Eng. Applied Sci., 9: 659-668. DOI: 10.3844/ajeassp.2016.659.668

Bedon, C., 2016. Review on the use of FRP composites for facades and building skins. Am. J. Eng. Applied Sci., 9: 713-723. DOI: 10.3844/ajeassp.2016.713.723

Bedon, C. and C. Amadio, 2016. A unified approach for the shear buckling design of structural glass walls with non-ideal restraints. Am. J. Eng. Applied Sci., 9: 64-78. DOI: 10.3844/ajeassp.2016.64.78 
Bedon, C. and C. Louter, 2016. Finite-element numerical simulation of the bending performance of posttensioned structural glass beams with adhesively bonded CFRP tendons. Am. J. Eng. Applied Sci., 9: 680-691. DOI: 10.3844/ajeassp.2016.680.691

Bolonkin, A., 2009a. Femtotechnology: Nuclear matter with fantastic properties. Am. J. Eng. Applied Sci., 2: 501-514. DOI: 10.3844/ajeassp.2009.501.514

Bolonkin, A., 2009b. Converting of matter to nuclear energy by ab-generator. Am. J. Eng. Applied Sci., 2: 683-693. DOI: 10.3844/ajeassp.2009.683.693

Boucetta, A., 2008. Vector control of a variable reluctance machine stator and rotor discs imbricates. Am. J. Eng. Applied Sci., 1: 260-265. DOI: 10.3844/ajeassp.2008.260.265

Bucinell, R.B., 2016. Stochastic model for variable amplitude fatigue induced delamination growth in graphite/epoxy laminates. Am. J. Eng. Applied Sci., 9: 635-646.

DOI: 10.3844/ajeassp.2016.635.646

Budak, S., Z. Xiao, B. Johnson, J. Cole and M. Drabo et al., 2016. Highly-efficient advanced thermoelectric devices from different multilayer thin films. Am. J. Eng. Applied Sci., 9: 356-363.

DOI: 10.3844/ajeassp.2016.356.363

Buonomano, A., F. Calise and M. Vicidomini, 2016a. A novel prototype of a small-scale solar power plant: Dynamic simulation and thermoeconomic analysis. Am. J. Eng. Applied Sci., 9: 770-788.

DOI: 10.3844/ajeassp.2016.770.788

Buonomano, A., F. Calise, M.D. d'Accadia, R. Vanoli and M. Vicidomini, 2016b. Simulation and experimental analysis of a demonstrative solar heating and cooling plant installed in Naples (Italy). Am. J. Eng. Applied Sci., 9: 798-813.

DOI: 10.3844/ajeassp.2016.798.813

Calise, F., M.D. dâ' Accadia, L. Libertini, E. Quiriti and M. Vicidomini, 2016. Dynamic simulation and optimum operation strategy of a trigeneration system serving a hospital. Am. J. Eng. Applied Sci., 9: 854-867. DOI: 10.3844/ajeassp.2016.854.867

Campo, T., M. Cotto, F. Marquez, E. Elizalde and C. Morant, 2016. Graphene synthesis by plasmaenhanced CVD growth with ethanol. Am. J. Eng. Applied Sci., 9: 574-583.

DOI: 10.3844/ajeassp.2016.574.583

Cardu, M., P. Oreste and T. Cicala, 2009. Analysis of the tunnel boring machine advancement on the BolognaFlorence railway link. Am. J. Eng. Applied Sci., 2: 416-420. DOI: 10.3844/ajeassp.2009.416.420

Chen, G. and L. Xu, 2016. A general strategy to enhance upconversion luminescence in rare-earth-ion-doped oxide nanocrystals. Am. J. Eng. Applied Sci., 9: 79-83. DOI: 10.3844/ajeassp.2016.79.83
Chiozzi, A., G. Milani, N. Grillanda and A. Tralli, 2016. An adaptive procedure for the limit analysis of FRP reinforced masonry vaults and applications. Am. J. Eng. Applied Sci., 9: 735-745.

DOI: 10.3844/ajeassp.2016.735.745

Chisari, C. and C. Bedon, 2016. Multi-objective optimization of FRP jackets for improving the seismic response of reinforced concrete frames. Am. J. Eng. Applied Sci., 9: 669-679.

DOI: 10.3844/ajeassp.2016.669.679

Darabi, A., S.A. Soleamani and A. Hassannia, 2008. Fuzzy based digital automatic voltage regulator of a synchronous generator with unbalanced loads. Am. J. Eng. Applied Sci., 1: 280-286.

DOI: 10.3844/ajeassp.2008.280.286

Daud, H., N. Yahya, A.A. Aziz and M.F. Jusoh, 2008. Development of wireless electric concept powering electrical appliances. Am. J. Eng. Applied Sci., 1: 12-15.

DOI: 10.3844/ajeassp.2008.12.15

dos Santos, F.A. and C. Bedon, 2016. Preliminary experimental and finite-element numerical assessment of the structural performance of SMAreinforced GFRP systems. Am. J. Eng. Applied Sci., 9: 692-701. DOI: 10.3844/ajeassp.2016.692.701

Djalel, D., M. Mourad and H. Labar, 2013. New approach of electromagnetic fields of the lightning discharge. Am. J. Eng. Applied Sci., 6: 369-383. DOI: 10.3844/ajeassp.2013.369.383

Ebrahim, N.A., S. Ahmed, S.H.A. Rashid and Z. Taha, 2012. Technology use in the virtual R\&D teams. Am. J. Eng. Applied Sci., 5: 9-14. DOI: 10.3844/ajeassp.2012.9.14

El-Labban, H.F., M. Abdelaziz and E.R.I. Mahmoud, 2013. Modification of carbon steel by laser surface melting: Part I: Effect of laser beam travelling speed on microstructural features and surface hardness. Am. J. Eng. Applied Sci., 6: 352-359. DOI: 10.3844/ajeassp.2013.352.359

Elliott, A., S. AlSalihi, A.L. Merriman and M.M. Basti, 2016. Infiltration of nanoparticles into porous binder jet printed parts. Am. J. Eng. Applied Sci., 9: 128-133.

DOI: 10.3844/ajeassp.2016.128.133

Elmeddahi, Y., H. Mahmoudi, A. Issaadi, M.F.A. Goosen and R. Ragab, 2016. Evaluating the effects of climate change and variability on water resources: A case study of the cheliff basin in Algeria. Am. J. Eng. Applied Sci., 9: 835-845. DOI: 10.3844/ajeassp.2016.835.845

El-Tous, Y., 2008. Pitch angle control of variable speed wind turbine. Am. J. Eng. Applied Sci., 1: 118-120. DOI: 10.3844/ajeassp.2008.118.120 
Faizal, A., S. Mulyono, R. Yendra and A. Fudholi, 2016. Design Maximum Power Point Tracking (MPPT) on photovoltaic panels using fuzzy logic method. Am. J. Eng. Applied Sci., 9: 789-797. DOI: 10.3844/ajeassp.2016.789.797

Farahani, A.S., N.M. Adam and M.K.A. Ariffin, 2010. Simulation of airflow and aerodynamic forces acting on a rotating turbine ventilator. Am. J. Eng. Applied Sci., 3: 159-170. DOI: 10.3844/ajeassp.2010.159.170

Fathallah, A.Z.M. and R.A. Bakar, 2009. Prediction studies for the performance of a single cylinder high speed spark ignition linier engine with spring mechanism as return cycle. Am. J. Eng. Applied Sci., 2: 713-720. DOI: 10.3844/ajeassp.2009.713.720

Fen, Y.W., W.M.M. Yunus, M.M. Moksin, Z.A. Talib and N.A. Yusof, 2011. Optical properties of crosslinked chitosan thin film with glutaraldehyde using surface Plasmon resonance technique. Am. J. Eng. Applied Sci., 4: 61-65. DOI: 10.3844/ajeassp.2011.61.65

Feraga, C.E., A. Moussaoui, A. Bouldjedri and A. Yousfi, 2009. Robust position controller for a permanent magnet synchronous actuator. Am. J. Eng. Applied Sci., 2: 388-392.

DOI: 10.3844/ajeassp.2009.388.392

Gusti, A.P. and Semin, 2016. The effect of vessel speed on fuel consumption and exhaust gas emissions. Am. J. Eng. Applied Sci., 9: 1046-1053. DOI: 10.3844/ajeassp.2016.1046.1053

Hassan, M., H. Mahjoub and M. Obed, 2012. Voice-based control of a DC servo motor. Am. J. Eng. Applied Sci., 5: 89-92. DOI: 10.3844/ajeassp.2012.89.92

Hasan, S. and M.H. El-Naas, 2016. Optimization of a combined approach for the treatment of carbide slurry and capture of $\mathrm{CO}_{2}$. Am. J. Eng. Applied Sci., 9: 449-457. DOI: 10.3844/ajeassp.2016.449.457

Helmy, A.K. and G.S. El-Taweel, 2010. Neural network change detection model for satellite images using textural and spectral characteristics. Am. J. Eng. Applied Sci., 3: 604-610.

DOI: 10.3844/ajeassp.2010.604.610

Hirun, W., 2016. Evaluation of interregional freight generation modelling methods by using nationwide commodity flow survey data. Am. J. Eng. Applied Sci., 9: 625-634. DOI: 10.3844/ajeassp.2016.625.634

Ho, C.Y.F., B.W.K. Ling, S.G. Blasi, Z.W. Chi and W.C. Siu, 2011. Single step optimal block matched motion estimation with motion vectors having arbitrary pixel precisions. Am. J. Eng. Applied Sci., 4: 448-460. DOI: 10.3844/ajeassp.2011.448.460

Huang, B., S.H. Masood, M. Nikzad, P.R. Venugopal and A. Arivazhagan, 2016. Dynamic mechanical properties of fused deposition modelling processed polyphenylsulfone material. Am. J. Eng. Applied Sci., 9: 1-11.

DOI: 10.3844/ajeassp.2016.1.11
Idarwazeh, S., 2011. Inverse discrete Fourier transform-discrete Fourier transform techniques for generating and receiving spectrally efficient frequency division multiplexing signals. Am. J. Eng. Applied Sci., 4: 598-606.

DOI: 10.3844/ajeassp.2011.598.606

Iqbal, M., 2016. An overview of Energy Loss Reduction (ELR) software used in Pakistan by WAPDA for calculating transformer overloading, line losses and energy losses. Am. J. Eng. Applied Sci., 9: 442-448. DOI: 10.3844/ajeassp.2016.442.448

Ismail, M.I.S., Y. Okamoto, A. Okada and Y. Uno, 2011. Experimental investigation on micro-welding of thin stainless steel sheet by fiber laser. Am. J. Eng. Applied Sci., 4: 314-320.

DOI: 10.3844/ajeassp.2011.314.320

Jaber, A.A. and R. Bicker, 2016. Industrial robot fault detection based on statistical control chart. Am. J. Eng. Applied Sci., 9: 251-263.

DOI: 10.3844/ajeassp.2016.251.263

Jafari, N., A. Alsadoon, C.P. Withana, A. Beg and A. Elchouemi, 2016. Designing a comprehensive security framework for smartphones and mobile devices. Am. J. Eng. Applied Sci., 9: 724-734. DOI: 10.3844/ajeassp.2016.724.734

Jalil, M.I.A. and J. Sampe, 2013. Experimental investigation of thermoelectric generator modules with different technique of cooling system. Am. J. Eng. Applied Sci., 6: 1-7.

DOI: 10.3844 ajeassp.2013.1.7

Jaoude, A.A. and K. El-Tawil, 2013. Analytic and nonlinear prognostic for vehicle suspension systems. Am. J. Eng. Applied Sci., 6: 42-56.

DOI: 10.3844/ajeassp.2013.42.56

Jarahi, H., 2016. Probabilistic seismic hazard deaggregation for Karaj City (Iran). Am. J. Eng. Applied Sci., 9: 520-529. DOI: 10.3844/ajeassp.2016.520.529

Jarahi, H. and S. Seifilaleh, 2016. Rock fall hazard zonation in Haraz highway. Am. J. Eng. Applied Sci., 9: 371-379.

DOI: $10.3844 /$ ajeassp.2016.371.379

Jauhari, K., A. Widodo and I. Haryanto, 2016. Identification of a machine tool spindle critical frequency through modal and imbalance response analysis. Am. J. Eng. Applied Sci., 9: 213-221.

DOI: 10.3844/ajeassp.2016.213.221

Jiang, J., Q. Chen and S. Nimbalkar, 2016. Field data based method for predicting long-term settlements. Am. J. Eng. Applied Sci., 9: 466-476.

DOI: 10.3844 /ajeassp.2016.466.476

Kaewnai, S. and S. Wongwises, 2011. Improvement of the runner design of Francis turbine using computational fluid dynamics. Am. J. Eng. Applied Sci., 4: 540-547.

DOI: 10.3844/ajeassp.2011.540.547 
Kamble, V.G. and N. Kumar, 2016. Fabrication and tensile property analysis of polymer matrix composites of graphite and silicon carbide as fillers. Am. J. Eng. Applied Sci., 9: 17-30. DOI: 10.3844/ajeassp.2016.17.30

Kazakov, V.V., V.I. Yusupov, V.N. Bagratashvili, A.I. Pavlikov and V.A. Kamensky, 2016. Control of bubble formation at the optical fiber tip by analyzing ultrasound acoustic waves. Am. J. Eng. Applied Sci., 9: 921-927. DOI: 10.3844/ajeassp.2016.921.927

Kechiche, O.B.H.B., H.B.A. Sethom, H. Sammoud and I.S. Belkhodja, 2011. Optimized high-frequency signal injection based permanent magnet synchronous motor rotor position estimation applied to washing machines. Am. J. Eng. Applied Sci., 4: 390-399. DOI: 10.3844/ajeassp.2011.390.399

Kuli, I., T.M. Abu-Lebdeh, E.H. Fini and S.A. Hamoush, 2016. The use of nano-silica for improving mechanical properties of hardened cement paste. Am. J. Eng. Applied Sci., 9: 146-154. DOI: 10.3844/ajeassp.2016.146.154

Kunanoppadon, J., 2010. Thermal efficiency of a combined turbocharger set with gasoline engine. Am. J. Eng. Applied Sci., 3: 342-349.

DOI: 10.3844/ajeassp.2010.342.349

Kwon, S., Y. Tani, H. Okubo and T. Shimomura, 2010. Fixed-star tracking attitude control of spacecraft using single-gimbal control moment gyros. Am. J. Eng. Applied Sci., 3: 49-55.

DOI: 10.3844/ajeassp.2010.49.55

Lamarre, A., E.H. Fini and T.M. Abu-Lebdeh, 2016. Investigating effects of water conditioning on the adhesion properties of crack sealant. Am. J. Eng. Applied Sci., 9: 178-186.

DOI: 10.3844/ajeassp.2016.178.186

Lubis, Z., A.N. Abdalla, Mortaza and R. Ghon, 2009. Mathematical modeling of the three phase induction motor couple to DC motor in hybrid electric vehicle. Am. J. Eng. Applied Sci., 2: 708-712. DOI: 10.3844/ajeassp.2009.708.712

Madani, D.A.L. and A. Dababneh, 2016. Rapid entire body assessment: A literature review. Am. J. Eng. Applied Sci., 9: 107-118.

DOI: 10.3844/ajeassp.2016.107.118

Malomar, G.E.B., A. Gueye, C. Mbow, V.B. Traore and A.C. Beye, 2016. Numerical study of natural convection in a square porous cavity thermally modulated on both side walls. Am. J. Eng. Applied Sci., 9: 591-598.

DOI: 10.3844 /ajeassp.2016.591.598

Mansour, M.A.A., 2016. Developing an anthropometric database for Saudi students and comparing Saudi dimensions relative to Turkish and Iranian peoples. Am. J. Eng. Applied Sci., 9: 547-557.

DOI: 10.3844/ajeassp.2016.547.557
Marghany, M. and M. Hashim, 2009. Robust of doppler centroid for mapping sea surface current by using radar satellite data. Am. J. Eng. Applied Sci., 2: 781-788.

DOI: $10.3844 /$ ajeassp.2009.781.788

Martins, F.R., A.R. Gonçalves and E.B. Pereira, 2016. Observational study of wind shear in Northeastern Brazil. Am. J. Eng. Applied Sci., 9: 484-504. DOI: 10.3844/ajeassp.2016.484.504

Mavukkandy, M.O., S. Chakraborty, T. Abbasi and S.A. Abbasi, 2016. A clean-green synthesis of platinum nanoparticles utilizing a pernicious weed lantana (Lantana Camara). Am. J. Eng. Applied Sci., 9: 84-90.

DOI: 10.3844/ajeassp.2016.84.90

Minghini, F., N. Tullini and F. Ascione, 2016. Updating Italian design guide CNR DT-205/2007 in view of recent research findings: Requirements for pultruded FRP profiles. Am. J. Eng. Applied Sci., 9: 702-712.

DOI: 10.3844/ajeassp.2016.702.712

Moezi, N., D. Dideban and A. Ketabi, 2008. A novel integrated SET based inverter for nano power electronic applications. Am. J. Eng. Applied Sci., 1: 219-222. DOI: 10.3844/ajeassp.2008.219.222

Mohamed, M.A., A.Y. Tuama, M. Makhtar, M.K. Awang and M. Mamat, 2016. The effect of RSA exponential key growth on the multi-core computational resource. Am. J. Eng. Applied Sci., 9: 1054-1061. DOI: 10.3844/ajeassp.2016.1054.1061

Mohan, K.S.R., P. Jayabalan and A. Rajaraman, 2012. Properties of fly ash based coconut fiber composite. Am. J. Eng. Applied Sci., 5: 29-34.

DOI: 10.3844/ajeassp.2012.29.34

Mohseni, E. and K.D. Tsavdaridis, 2016. Effect of nanoalumina on pore structure and durability of class $\mathrm{F}$ fly ash self-compacting mortar. Am. J. Eng. Applied Sci., 9: 323-333. DOI: 10.3844/ajeassp.2016.323.333

Momani, M.A., T.A. Al Smadi, FM. Al Taweel and K.A. Ghaidan, 2011. GPS ionospheric total electron content and scintillation measurements during the October 2003 magnetic storm. Am. J. Eng. Applied Sci., 4: 301-306.

DOI: 10.3844/ajeassp.2011.301.306

Mondal, R., S. Sahoo and C.S. Rout, 2016. Mixed nickel cobalt manganese oxide nanorods for supercapacitor application. Am. J. Eng. Applied Sci., 9: 540-546. DOI: 10.3844/ajeassp.2016.540.546

Montgomery, J., T.M. Abu-Lebdeh, S.A. Hamoush and M. Picornell, 2016. Effect of nano-silica on the compressive strength of harden cement paste at different stages of hydration. Am. J. Eng. Applied Sci., 9: 166-177.

DOI: $10.3844 /$ ajeassp.2016.166.177 
Morse, A., M.M. Mansfield, R.M. Alley, H.A. Kerr and R.B. Bucinell, 2016. Traction enhancing products affect maximum torque at the shoe-floor interface: A potential increased risk of ACL injury. Am. J. Eng. Applied Sci., 9: 889-893.

DOI: 10.3844/ajeassp.2016.889.893

Moubarek, T. and A. Gharsallah, 2016. A six-port reflectometer calibration using Wilkinson power divider. Am. J. Eng. Applied Sci., 9: 274-280. DOI: 10.3844/ajeassp.2016.274.280

Nabilou, A., 2016a. Effect of parameters of selection and replacement drilling bits based on geo-mechanical factors: (case study: Gas and oil reservoir in the Southwest of Iran). Am. J. Eng. Applied Sci., 9: 380-395. DOI: 10.3844/ajeassp.2016.380.395

Nabilou, A., 2016b. Study of the parameters of Steam Assisted Gravity Drainage (SAGD) method for enhanced oil recovery in a heavy oil fractured carbonate reservoir. Am. J. Eng. Applied Sci., 9: 647-658. DOI: 10.3844/ajeassp.2016.647.658

Nachiengtai, T., W. Chim-Oye, S. Teachavorasinskun and W. Sa-Ngiamvibool, 2008. Identification of shear band using elastic shear wave propagation. Am. J. Eng. Applied Sci., 1: 188-191.

DOI: 10.3844/ajeassp.2008.188.191

Nahas, R. and S.P. Kozaitis, 2014. Metric for the fusion of synthetic and real imagery from multimodal sensors. Am. J. Eng. Applied Sci., 7: 355-362. DOI: 10.3844/ajeassp.2014.355.362

Nandhakumar, S., V. Selladurai and S. Sekar, 2009. Numerical investigation of an industrial robot arm control problem using haar wavelet series. Am. J. Eng. Applied Sci., 2: 584-589.

DOI: 10.3844/ajeassp.2009.584.589

Ng, K.C., M.Z. Yusoff, K. Munisamy, H. Hasini and N.H. Shuaib, 2008. Time-marching method for computations of high-speed compressible flow on structured and unstructured grid. Am. J. Eng. Applied Sci., 1: 89-94.

DOI: 10.3844/ajeassp.2008.89.94

Obaiys, S.J., Z. Abbas, N.M.A. Nik Long, A.F. Ahmad and A. Ahmedov et al., 2016. On the general solution of first-kind hypersingular integral equations. Am. J. Eng. Applied Sci., 9: 195-201. DOI: 10.3844/ajeassp.2016.195.201

Odeh, S., R. Faqeh, L. Abu Eid and N. Shamasneh, 2009. Vision-based obstacle avoidance of mobile robot using quantized spatial model. Am. J. Eng. Applied Sci., 2: 611-619.

DOI: 10.3844/ajeassp.2009.611.619

Opafunso, Z.O., I.I. Ozigis and I.A. Adetunde, 2009. Pneumatic and hydraulic systems in coal fluidized bed combustor. Am. J. Eng. Applied Sci., 2: 88-95. DOI: 10.3844/ajeassp.2009.88.95
Orlando, N. and E. Benvenuti, 2016. Advanced XFEM simulation of pull-out and debonding of steel bars and FRP-reinforcements in concrete beams. Am. J. Eng. Applied Sci., 9: 746-754.

DOI: 10.3844/ajeassp.2016.746.754

Pannirselvam, N., P.N. Raghunath and K. Suguna, 2008. Neural network for performance of glass fibre reinforced polymer plated RC beams. Am. J. Eng. Applied Sci., 1: 82-88.

DOI: 10.3844 /ajeassp.2008.82.88

Pattanasethanon, S., 2010. The solar tracking system by using digital solar position sensor. Am. J. Eng. Applied Sci., 3: 678-682. DOI: 10.3844/ajeassp.2010.678.682

Pérez-de León, G., V.E. Lamberti, R.D. Seals, T.M. Abu-Lebdeh and S.A. Hamoush 2016. Gas atomization of molten metal: Part I. Numerical modeling conception. Am. J. Eng. Applied Sci., 9: 303-322. DOI: 10.3844/ajeassp.2016.303.322

Petrescu, F. and R. Petrescu, 1995a. Contributions to the optimization of the polynomial motion laws of the stick from the internal combustion engine distribution mechanism. Bucharest.

Petrescu, F. and R. Petrescu, 1995b. Contributions to the synthesis of distribution mechanisms of internal combustion engines. Bucharest.

Petrescu, F. and R. Petrescu, 1997a. Dynamics of cam mechanisms (exemplified on the classic distribution mechanism). Bucharest.

Petrescu, F. and R. Petrescu, 1997b. Contributions to the synthesis of the distribution mechanisms of internal combustion engines with Cartesian coordinate method. Bucharest.

Petrescu, F. and R. Petrescu, 1997c. Contributions to the maximization of polynomial laws for the active stroke of the distribution mechanism from internal combustion engines. Bucharest.

Petrescu, F. and R. Petrescu, 2000a. Synthesis of distribution mechanisms by the rectangular coordinate method (Cartesian). Craiova University, Craiova.

Petrescu, F. and R. Petrescu, 2000b. The design (synthesis) of cam mechanism by the polar coordinates method (triangle method). Craiova University, Craiova.

Petrescu, F. and R. Petrescu, 2002a. Motion laws for cam mechanisms. Proceedings of the 7th National Symposium with International Participation Computer Assisted Design, (CAD’ 02), Braşov, pp: 321-326.

Petrescu, F. and R. Petrescu, 2002b. Dynamics of cam mechanisms. Proceedings of the National Symposium with International Participation Computer Assisted Design, (CAD’ 02), Brasov, pp: 327-332.

Petrescu, F. and R. Petrescu, 2003. Some elements regarding the improvement of the engine design. Proceedings of the 8th National Symposium, Descriptive Geometry, Technical Graphics and Design, (GTD’ 03), Braşov, pp: 353-358. 
Petrescu, F. and R. Petrescu, 2005a. The cam design for a better efficiency. Proceedings of the International Conference on Engineering Graphics and Design, (EGD’ 05), Bucharest, pp: 245-248.

Petrescu, F. and R. Petrescu, 2005b. Contributions at the dynamics of cams. Proceedings of the 9th IFToMM International Symposium on Theory of Machines and Mechanisms, (TMM' 05), Bucharest, Romania, pp: 123-128.

Petrescu, F. and R. Petrescu, 2005c. Determining the dynamic efficiency of cams. Proceedings of the 9 th IFToMM International Symposium on Theory of Machines and Mechanisms, (TMM' 05), Bucharest, Romania, pp: 129-134.

Petrescu, F. and R. Petrescu, 2005d. An original internal combustion engine. Proceedings of the 9th IFToMM International Symposium on Theory of Machines and Mechanisms, (TMM' 05), Bucharest, Romania, pp: 135-140.

Petrescu, F. and R. Petrescu, 2005e. Determining the mechanical efficiency of Otto engine's mechanism. Proceedings of the 9th IFToMM International Symposium on Theory of Machines and Mechanisms, (TMM’05), Bucharest, Romania, pp: 141-146.

Petrescu, R.V. and F.I. Petrescu, 2013a. Lockheed Martin. 1st Edn., BoD-Books on Demand, ISBN-10: 3848230739, pp: 114.

Petrescu, R.V. and F.I. Petrescu, 2013b. Northrop. 1st Edn., CreateSpace, pp: 96.

Petrescu, R.V. and F.I. Petrescu, 2013c. The Aviation History or New Aircraft I Color. 1st Edn., CreateSpace, pp: 292.

Petrescu, F.I.T. and R.V. Petrescu, 2013d. Forces and efficiency of cams. Int. Rev. Mech. Eng. J., 7: 507-511.

Petrescu, F.I.T. and R.V. Petrescu, 2013e. Cams with high efficiency. Int. Rev. Mech. Eng. J., 7: 599-606.

Petrescu, F.I.T. and R.V. Petrescu, 2013f. An algorithm for setting the dynamic parameters of the classic distribution mechanism. Int. Rev. Modell. Simulat. J., 6: 1637-1641.

Petrescu, F.I.T. and R.V. Petrescu, 2013g. Dynamic synthesis of the rotary cam and translated tappet with roll. Int. Rev. Modell. Simulat. J., 6: 600-607.

Petrescu, F.I. and R.V. Petrescu, 2012. New Aircraft II. 1st Edn., Books On Demand, pp: 138.

Petrescu, F.I. and R.V. Petrescu, 2011. Memories about Flight. 1st Edn., CreateSpace, pp: 652.

Petrescu, F.I.T. and R.V. Petrescu, 2014a. Parallel moving mechanical systems. Independent $\mathrm{J}$. Manage. Product., 5: 564-580.

Petrescu, F.I.T. and R.V. Petrescu, 2014b. Cam gears dynamics in the classic distribution. Independent J. Manage. Product., 5: 166-185.

Petrescu, F.I.T. and R.V. Petrescu, 2014c. Highefficiency gears synthesis by avoid the interferences. Independent J. Manage. Product., 5: 275-298.
Petrescu, F.I.T. and R.V. Petrescu, 2014d. Gear design. J. ENGEVISTA, 16: 313-328.

Petrescu, F.I.T. and R.V. Petrescu, 2014e. Kinetostatic of the 3R dyad (or 2R Module). J. ENGEVISTA, 16: 314-321.

Petrescu, F.I.T. and R.V. Petrescu, 2014f. Balancing Otto engines. Int. Rev. Mech. Eng. J., 8: 473-480.

Petrescu, F.I.T. and R.V. Petrescu, 2014g. Machine equations to the classical distribution. Int. Rev. Mech. Eng. J., 8: 309-316.

Petrescu, F.I.T. and R.V. Petrescu, 2014h. Forces of internal combustion heat engines. Int. Rev. Modell. Simulat. J., 7: 206-212.

Petrescu, F.I.T. and R.V. Petrescu, 2014i. Determination of the yield of internal combustion thermal engines. Int. Rev. Mech. Eng. J., 8: 62-67.

Petrescu, F.I.T. and R.V. Petrescu, 2015a. Forces at the main mechanism of a railbound forging manipulator. Independent J. Manage. Product., 6: 904-921.

Petrescu, F.I.T. and R.V. Petrescu, 2015b. Kinematics at the main mechanism of a railbound forging manipulator. Independent J. Manage. Product., 6: 711-729.

Petrescu, F.I.T. and R.V. Petrescu, 2015c. Machine motion equations. Independent J. Manage. Product., 6: 773-802.

Petrescu, F.I.T. and R.V. Petrescu, 2015d. Presenting a railbound forging manipulator. Applied Mechan. Mater., 762: 219-224.

Petrescu, F.I.T. and R.V. Petrescu, 2015e. About the anthropomorphic robots. J. ENGEVISTA, 17: 1-15

Petrescu, F.I.T. and R.V. Petrescu, 2016. An Otto engine dynamic model. Independent J. Manage. Product., 7: 038-048.

Petrescu, F.I.T., 2018. About the nuclear particles' structure and dimensions. Comp. Part. Mech. DOI: $10.1007 / \mathrm{s} 40571-018-0206-7$

Petrescu, F.I.T., 2015a. Geometrical synthesis of the distribution mechanisms. Am. J. Eng. Applied Sci., 8: 63-81. DOI: 10.3844/ajeassp.2015.63.81

Petrescu, F.I.T., 2015b. Machine motion equations at the internal combustion heat engines. Am. J. Eng. Applied Sci., 8: 127-137. DOI: 10.3844/ajeassp.2015.127.137

Petrescu, F.I.T., 2012a. Cold nuclear fusion. Plasma Phys. Fus. Technol., 44: 100-100.

Petrescu, F.I.T., A. Apicella, R.V. Petrescu, S.P. Kozaitis and R.B. Bucinell et al., 2016. Environmental protection through nuclear energy. Am. J. Applied Sci., 13: 941-946.

Petrescu, R.V., R. Aversa, B. Akash, F. Berto and A. Apicella et al., 2017a. Forces of a 3R robot. J. Mechatron. Robot., 1: 1-14. DOI: $10.3844 /$ jmrsp.2017.1.14

Petrescu, R.V., R. Aversa, B. Akash, F. Berto and A. Apicella et al., 2017b. Direct geometry and cinematic to the MP-3R systems. J. Mechatron. Robot., 1: 15-23. DOI: 10.3844/jmrsp.2017.15.23 
Petrescu, R.V., R. Aversa, B. Akash, F. Berto and A. Apicella et al., 2017c. Dynamic elements at MP3R. J. Mechatron. Robot., 1: 24-37. DOI: 10.3844/jmrsp.2017.24.37

Petrescu, R.V., R. Aversa, B. Akash and A. Apicella et al., 2017d. Geometry and direct kinematics to MP3R with $4 \times 4$ operators. J. Mechatron. Robot., 1: 38-46. DOI: 10.3844/jmrsp.2017.38.46

Petrescu, R.V., R. Aversa, A. Apicella and F.I.T. Petrescu, 2018a. Total Static Balancing and Kinetostatics of the 3R Base Cinematic Chain. J. Mechatron. Robot., 2: 1-13.

DOI: $10.3844 /$ jmrsp.2018.1.13

Petrescu, R.V., R. Aversa, A. Apicella and F.I.T. Petrescu, 2018b. Switching from Flat to Spatial Motion to 3R Mechatronic Systems. J. Mechatron. Robot., 2: 14-22. DOI: 10.3844/jmrsp.2018.14.22

Petrescu, R.V., R. Aversa, A. Apicella and F.I.T. Petrescu, 2018c. The dynamics of the planar cinematic balanced chain at the plan module 3R. J. Mechatron. Robot., 2: 23-34. DOI: 10.3844/jmrsp.2018.23.34

Petrescu, R.V., R. Aversa, A. Apicella and F.I.T. Petrescu, 2018d. Dynamic Kinematics of the Plan Balanced Chain at the Planar Module 3R. J. Mechatron. Robot., 2: 35-44.

DOI: $10.3844 /$ jmrsp.2018.35.44

Petrescu, F.I.T. and J.K. Calautit, 2016a. About nano fusion and dynamic fusion. Am. J. Applied Sci., 13: 261-266.

Petrescu, F.I.T. and J.K. Calautit, 2016b. About the light dimensions. Am. J. Applied Sci., 13: 321-325.

Petrescu FIT., 2012b. China. CreateSpace Independent Publisher, 232 pages, ISBN-13: 978-1469973623

Pisello, A.L., G. Pignatta, C. Piselli, V.L. Castaldo and F. Cotana, 2016. Investigating the dynamic thermal behavior of building envelope in summer conditions by means of in-field continuous monitoring. Am. J. Eng. Applied Sci., 9: 505-519.

DOI: 10.3844/ajeassp.2016.505.519

Pourmahmoud, N., 2008. Rarefied gas flow modeling inside rotating circular cylinder. Am. J. Eng. Applied Sci., 1: 62-65.

DOI: 10.3844/ajeassp.2008.62.65

Pravettoni, M., C.S.P. Lòpez and R.P. Kenny, 2016. Impact of the edges of a backside diffusive reflector on the external quantum efficiency of luminescent solar concentrators: experimental and computational approach. Am. J. Eng. Applied Sci., 9: 53-63.

DOI: 10.3844 /ajeassp.2016.53.63

Qutbodin, K., 2010. Merging autopilot/flight control and navigation-flight management systems. Am. J. Eng. Applied Sci., 3: 629-630.

DOI: 10.3844/ajeassp.2010.629.630
Rajbhandari, S., Z. Ghassemlooy and M. Angelova, 2011. The performance of a dual header pulse interval modulation in the presence of artificial light interferences in an indoor optical wireless communications channel with wavelet denoising. Am. J. Eng. Applied Sci., 4: 513-519.

DOI: 10.3844/ajeassp.2011.513.519

Rajput, R.S., S. Pandey and S. Bhadauria, 2016. Correlation of biodiversity of algal genera with special reference to the waste water effluents from industries. Am. J. Eng. Applied Sci., 9: 1127-1133. DOI: 10.3844/ajeassp.2016.1127.1133

Raptis, K.G., G.A. Papadopoulos, T.N. Costopoulos and A.D. Tsolakis, 2011. Experimental study of load sharing in roller-bearing contact by caustics and photoelasticity. Am. J. Eng. Applied Sci., 4: 294-300. DOI: 10.3844/ajeassp.2011.294.300

Rama, G., D. Marinkovic and M. Zehn, 2016. Efficient co-rotational 3-node shell element. Am. J. Eng. Applied Sci., 9: 420-431.

DOI: 10.3844/ajeassp.2016.420.431

Rea, P. and E. Ottaviano, 2016. Analysis and mechanical design solutions for sit-to-stand assisting devices. Am. J. Eng. Applied Sci., 9: 1134-1143. DOI: 10.3844/ajeassp.2016.1134.1143

Riccio, A., U. Caruso, A. Raimondo and A. Sellitto, 2016a. Robustness of XFEM method for the simulation of cracks propagation in fracture mechanics problems. Am. J. Eng. Applied Sci., 9: 599-610. DOI: 10.3844/ajeassp.2016.599.610

Riccio, A., R. Cristiano and S. Saputo, 2016b. A brief introduction to the bird strike numerical simulation. Am. J. Eng. Applied Sci., 9: 946-950. DOI: 10.3844/ajeassp.2016.946.950

Rich, F. and M.A. Badar, 2016. Statistical analysis of auto dilution Vs manual dilution process in inductively coupled plasma spectrometer tests. Am. J. Eng. Applied Sci., 9: 611-624.

DOI: 10.3844/ajeassp.2016.611.624

Rohit, K. and S. Dixit, 2016. Mechanical properties of waste Biaxially Oriented Polypropylene Metallized Films (BOPP), LLDPE: LDPE Films with Sisal Fibres. Am. J. Eng. Applied Sci., 9: 913-920. DOI: 10.3844/ajeassp.2016.913.920

Rulkov, N.F., A.M. Hunt, P.N. Rulkov and A.G. Maksimov, 2016. Quantization of map-based neuronal model for embedded simulations of neurobiological networks in real-time. Am. J. Eng. Applied Sci., 9: 973-984.

DOI: 10.3844/ajeassp.2016.973.984

Saal, A.E., E.H. Hauri, M.L. Cascio, J.A. van Orman and M.C. Rutherford et al., 2008. Volatile content of lunar volcanic glasses and the presence of water in the Moon's interior. Nature, 454: 192-195. DOI: $10.1038 /$ nature 07047 
Saikia, A. and N. Karak, 2016. Castor oil based epoxy/clay nanocomposite for advanced applications. Am. J. Eng. Applied Sci., 9: 31-40. DOI: 10.3844/ajeassp.2016.31.40

Sallami, A., N. Zanzouri and M. Ksouri, 2016. Robust diagnosis of a DC motor by bond graph approach. Am. J. Eng. Applied Sci., 9: 432-438.

DOI: 10.3844/ajeassp.2016.432.438

Samantaray, K.S., S. Sahoo and C.S. Rout, 2016. Hydrothermal synthesis of $\mathrm{CuWO}_{4}$-reduced graphene oxide hybrids and supercapacitor application. Am. J. Eng. Applied Sci., 9: 584-590. DOI: 10.3844/ajeassp.2016.584.590

Semin, A.R. Ismail and R.A. Bakar, 2009a. Combustion temperature effect of diesel engine convert to compressed natural gas engine. Am. J. Eng. Applied Sci., 2: 212-216.

DOI: 10.3844/ajeassp.2009.212.216

Semin, A.R. Ismail and R.A. Bakar, 2009b. Effect of diesel engine converted to sequential port injection compressed natural gas engine on the cylinder pressure Vs crank angle in variation engine speeds. Am. J. Eng. Applied Sci., 2: 154-159.

DOI: 10.3844/ajeassp.2009.154.159

Semin S., A.R. Ismail and R.A. Bakar, 2009c. Diesel engine convert to port injection $\mathrm{CNG}$ engine using gaseous injector nozzle multi holes geometries improvement: A review. Am. J. Eng. Applied Sci., 2: 268-278. DOI: 10.3844/ajeassp.2009.268.278

Semin and R.A. Bakar, 2008. A technical review of compressed natural gas as an alternative fuel for internal combustion engines. Am. J. Eng. Applied Sci., 1: 302-311. DOI: 10.3844/ajeassp.2008.302.311

Sepúlveda, J.A.M., 2016. Outlook of municipal solid waste in Bogota (Colombia). Am. J. Eng. Applied Sci., 9: 477-483.

DOI: 10.3844/ajeassp.2016.477.483

Serebrennikov, A., D. Serebrennikov and Z. Hakimov, 2016. Polyethylene pipeline bending stresses at an installation. Am. J. Eng. Applied Sci., 9: 350-355. DOI: 10.3844 /ajeassp.2016.350.355

Shanmugam, K., 2016. Flow dynamic behavior of fish oil/silver nitrate solution in mini-channel, effect of alkane addition on flow pattern and interfacial tension. Am. J. Eng. Applied Sci., 9: 236-250. DOI: 10.3844/ajeassp.2016.236.250

Shruti, 2016. Comparison in cover media under stegnography: Digital media by hide and seek approach. Am. J. Eng. Applied Sci., 9: 297-302. DOI: 10.3844/ajeassp.2016.297.302

Suarez, L., T.M. Abu-Lebdeh, M. Picornell and S.A. Hamoush, 2016. Investigating the role of fly ash and silica fume in the cement hydration process. Am. J. Eng. Applied Sci., 9: 134-145.

DOI: 10.3844/ajeassp.2016.134.145
Syahrullah, O.I. and N. Sinaga, 2016. Optimization and prediction of motorcycle injection system performance with feed-forward back-propagation method Artificial Neural Network (ANN). Am. J. Eng. Applied Sci., 9: 222-235.

DOI: 10.3844/ajeassp.2016.222.235

Taher, S.A., R. Hematti and M. Nemati, 2008. Comparison of different control strategies in GAbased optimized UPFC controller in electric power systems. Am. J. Eng. Applied Sci., 1: 45-52. DOI: 10.3844 /ajeassp.2008.45.52

Theansuwan, W. and K. Triratanasirichai, 2011. The biodiesel production from roast Thai sausage oil by transesterification reaction. Am. J. Eng. Applied Sci., 4: 130-132.

DOI: 10.3844/ajeassp.2011.130.132

Thongwan, T., A. Kangrang and S. Homwuttiwong, 2011. An estimation of rainfall using fuzzy setgenetic algorithms model. Am. J. Eng. Applied Sci., 4: 77-81. DOI: 10.3844/ajeassp.2011.77.81

Tourab, W., A. Babouri and M. Nemamcha, 2011. Experimental study of electromagnetic environment in the vicinity of high voltage lines. Am. J. Eng. Applied Sci., 4: 209-213.

DOI: 10.3844/ajeassp.2011.209.213

Tsolakis, A.D. and K.G. Raptis, 2011. Comparison of maximum gear-tooth operating bending stresses derived from niemann's analytical procedure and the finite element method. Am. J. Eng. Applied Sci., 4: 350-354. DOI: 10.3844/ajeassp.2011.350.354

Wang, L., T. Liu, Y. Zhang and X. Yuan, 2016. A methodology for continuous evaluation of cloud resiliency. Am. J. Eng. Applied Sci., 9: 264-273. DOI: 10.3844/ajeassp.2016.264.273

Wang, J. and Y. Yagi, 2016. Fragment-based visual tracking with multiple representations. Am. J. Eng. Applied Sci., 9: 187-194. DOI: 10.3844/ajeassp.2016.187.194

Waters, C., S. Ajinola and M. Salih, 2016. Dissolution sintering technique to create porous copper with sodium chloride using polyvinyl alcohol solution through powder metallurgy. Am. J. Eng. Applied Sci., 9: 155-165. DOI: 10.3844/ajeassp.2016.155.165

Wessels, L. and H. Raad, 2016. Recent advances in point of care diagnostic tools: A review. Am. J. Eng. Applied Sci., 9: 1088-1095.

DOI: 10.3844/ajeassp.2016.1088.1095

Williams, J.G. S.G. Turyshev, D.H. Boggs and J.T. Ratcliff, 2006. Lunar laser ranging science: Gravitational physics and lunar interior and geodesy. Adv. Space Res., 37: 67-71. DOI: 10.1016/j.asr.2005.05.013.

Yeargin, R., R. Ramey and C. Waters, 2016. Porosity analysis in porous brass using dual approaches. Am. J. Eng. Applied Sci., 9: 91-97. DOI: 10.3844/ajeassp.2016.91.97 
You, M., X. Huang, M. Lin, Q. Tong and X. Li et al., 2016. Preparation of $\mathrm{LiCoMnO}_{4}$ assisted by hydrothermal approach and its electrochemical performance. Am. J. Eng. Applied Sci., 9: 396-405. DOI: 10.3844/ajeassp.2016.396.405

Zeferino, R.S., J.A.R. Ramón, E. de Anda Reyes, R.S. González and U. Pal, 2016. Large scale synthesis of $\mathrm{ZnO}$ nanostructures of different morphologies through solvent-free mechanochemical synthesis and their application in photocatalytic dye degradation. Am. J. Eng. Applied Sci., 9: 41-52. DOI: 10.3844 /ajeassp.2016.41.52

Zhao, B., 2013. Identification of multi-cracks in the gate rotor shaft based on the wavelet finite element method. Am. J. Eng. Applied Sci., 6: 309-319.

DOI: 10.3844/ajeassp.2013.309.319

Zheng, H. and S. Li, 2016. Fast and robust maximum power point tracking for solar photovoltaic systems. Am. J. Eng. Applied Sci., 9: 755-769.

DOI: 10.3844/ajeassp.2016.755.769

Zotos, I.S. and T.N. Costopoulos, 2009. On the use of rolling element bearings' models in precision maintenance. Am. J. Eng. Applied Sci., 2: 344-352. DOI: 10.3844/ajeassp.2009.344.352

Zulkifli, R., K. Sopian, S. Abdullah and M.S. Takriff, 2008. Effect of pulsating circular hot air jet frequencies on local and average nusselt number. Am. J. Eng. Applied Sci., 1: 57-61.

DOI: 10.3844/ajeassp.2008.57.61

Zulkifli, R., K. Sopian, S. Abdullah and M.S. Takriff, 2009. Experimental study of flow structures of circular pulsating air jet. Am. J. Eng. Applied Sci., 2: 171-175.

DOI: $10.3844 /$ ajeassp.2009.171.175
Zurfi, A. and J. Zhang, 2016a. Model identification and wall-plug efficiency measurement of white LED modules. Am. J. Eng. Applied Sci., 9: 412-419. DOI: 10.3844/ajeassp.2016.412.419

Zurfi, A. and J. Zhang, 2016b. Exploitation of battery energy storage in load frequency control -A literature survey. Am. J. Eng. Applied Sci., 9: 1173-1188. DOI: 10.3844/ajeassp.2016.1173.1188

\section{Source of Figures}

Fig. 1

https://en.wikipedia.org/wiki/Moon\#/media/File:Full Moon2010.jpg

Fig. 2

https://en.wikipedia.org/wiki/Moon\#/media/File:Luna r_eclipse_October_8_2014_California_Alfredo_Garcia_ Jr_mideclipse.JPG

Fig. 3

https://ro.wikipedia.org/wiki/Luna\#/media/Fi\%C8\%9 9ier:Moon-craters.jpg

Fig. 4

https://ziare.com/magazin/spatiu/nasa-face-noidezvaluiri-despre-structura-interna-a-lunii-1067144

Fig. 5

https://ro.wikipedia.org/wiki/Luna\#/media/Fi\%C8\%9 9ier:Reiner-gamma-clem1.jpg

Fig. 6

http://www.prisma-online.ro/wp/wpcontent/uploads/2018/08/statia-lunara-640x356.jpg

Fig. 7

https://storage0.dms.mpinteractiv.ro/media/401/321/5 109/19118707/1/gateway2nasa.jpg? width $=618 \&$ height $=361$ 